\title{
CHRONICA
}

\section{Za 65. rođendan Istvána Viga}

Posljednji put prije pet godina, akademik István Nyomárkay uputio je čestitke našem dragom kolegi Istvánu Vigu na stranama ovog časopisa. Ovom prilikom, želio bih dati pregled dosadašnjih istraživačkih i nastavničkih dostignuća i tema profesora Viga, nadajući se da će mi uspijeti uz bogatstvo znanstvene i profesorne karijere prikazati i Istvána Viga - čovjeka i bivšeg, ali veoma dragog, profesora.

István Vig je rođen 1. listopada 1952. godine u Budimpešti. Osnovnu školu i gimnaziju je pohađao u 12. budimpeštanskom kvartu, gdje je njegova obitelj živjela. Već u višim razredima osnovne škole počeo je privatno učiti francuski. Njegovo veliko oduševljenje romanskim jezicima pokazuje i činjenica da se u gimnaziji opredijelio za talijanski jezik te je tako do kraja gimnazije naučio dva velika romanska jezika. Nakon mature upisao se na studij povijesti i talijanskog jezika s književnošću na Filozofski fakultet Sveučilišta Loránda Eötvösa u Budimpešti, na kojem je uspješno diplomirao 1978. g.

Odmah nakon stjecanja diplome zaposlen je kao asistent na Odsjeku za talijanski jezik i književnost, gdje je ostao sve do 1994. godine, kada je prešao na Odsjek za slavensku filologiju, tako da je niz godina usporedno predavao i na kroatistici i talijanistici. Na talijanistici je predavao povijesni razvoj talijanskog jezika, dijalektologiju i sintaksu. Na kroatistici je predavao gramatiku, leksikologiju, frazeologiju, lingvistiku teksta, sociolingvistiku i stilistiku. Doktorirao je 1985. godine iz romanistike. Zahvaljujući stipendijama, više je puta boravio u Italiji, u Bologni i u Trstu. Boravak u Trstu iskoristio je na detaljnije proučavanje i istraživanje talijansko-hrvatskih jezičnih kontakata koji su mu uvijek bili omiljena tema jer predstavljaju most između talijanistike i kroatistike. 1998. godine, već kao suradnik Odsjeka za slavensku filologiju, izabran je za docenta. Od 2007. g. je habilitirani docent na istom Odsjeku, od 2014. godine je redoviti profesor. 2011. godine stječe titulu doktora jezikoslovlja pri Akademiji znanosti Mađarske.

Profesora Viga kao istraživača zanimaju povijest jezika, jezični kontakti, etimologija, pitanje dvojezičnosti, odnosno višejezičnosti i povijesna leksikografija. Ove teme predstavljaju osnovu njegovih znanstvenih publikacija, čak možemo reći da ga ove teme prate od samog početka istraživanja. Budući da je počeo svoju znanstvenu karijeru kao talijanist, u prvom desetljeću njegovih istraživanja nalazimo publikacije iz oblasti talijanskog jezika. Međutim, znanje talijanskog jezika imalo je ključnu ulogu i u njegovoj kroatističkoj karijeri. Naime, prva tema koja ga je povezala s kroatistikom bili su italoromanski-hrvatski jezični kontakti. U drugoj polovici osamdesetih godina radi boljeg i svestranijeg upoznavanja teme naučio je i hrvatski jezik. Time je započeo njegov rad na području kroatistike koji traje sve do danas. Možemo reći da se profesor Vig iz talijanista razvio u kroatista, mada nikad nije zaboravio svoje korijene i često im se vraćao. Svoje prve kroatističke rasprave objavljivao je na francuskom i talijanskom jeziku, ali ih je kasnije počeo pisati, i još uvijek piše, na hrvatskom jeziku kojem je nakon nekog vremena pridružio i njemački kao jezik na kojem objavljuje svoje publikacije. Njegove samostalne znanstvene monografije su Sprachkontakte im Alpen-Adria-Raum (2007), Horvát nyelvtan [Hrvatska gramatika] (2008) i Verancsics Faustus Dictionariuma a korabeli európai kontextusban [Vrančićev 
Dictionarium u suvremenom europskom kontekstu] (2011). U monografiji Sprachkontakte objavljeno je njegovih 10 prerađenih rasprava podijeljenih u četiri tematska poglavlja. Rasprave predstavljaju određene probleme i pitanja arealnih, italoromansko-hrvatskih, talijansko-mađarskih i mađarsko-hrvatskih kontakata. Te su rasprave pisane na francuskom, talijanskom, hrvatskom, mađarskom i njemačkom jeziku, a za monografiju su sve prevedene na njemački jezik. Ova monografija predstavlja dobar zaključak dugogodišnjih istraživanja na području kontaktnog jezikoslovlja, tzv. kontaktologije. Prema riječima samog autora, gramatiku pod naslovom Horvát nyelvtan napisao je radi dvije važne namjere. S jedne strane zbog nastavničkih potreba hrvatske gramatike, s druge strane želi biti i priručnik hrvatske gramatike na mađarskom jeziku svima koje zanima hrvatski jezik. Ova gramatika pripada tzv. gramatikama zavisnosti koje imaju bogatu tradiciju na francuskom i njemačkom jezičnom tlu, a sada je to načelo prvi put upotrijebljeno za opis hrvatskog jezika. Gramatika sadrži sve tradicionalne dijelove gramatike, nedostaju jedino fonetika i fonologija. Umjesto njih ima dodatno uvodno poglavlje s tumačenjem glavnih pojmova gramatike zavisnosti. Posebno je poglavlje posvećeno za predstavljanju onih jezičnih i gramatičkih pojava koje utječu na više razina jezika. Zadnja monografija profesora Viga bavi se povijesnom leksikografijom i jednim vrhunskim dostignućem hrvatske leksikografije - petojezičnim rječnikom Fausta Vrančića. Godinama se bavio istraživanjem ovog rječnika, koji mu je bio i tema za habilitaciju. Kao plod ovog višegodišnjeg istraživanja objelodanjena je njegova monografija o Vrančiću i njegovu rječniku. Ova je monografija klasičan primjer bogate filološke metode kojom je autor odgovorio na pojedina zamršena pitanja u vezi s Vrančićem i njegovim rječnikom, kao šti su na primjer pitanje Vrančićeva znanja jezika, izvori rječnika, itd.

István Vig je bio suautor vježbenice iz talijanske gramatike (Esercizi di grammatica italiana, prvo izdanje 1992. g.) i sastavio je bibliografiju talijanistike u Mađarskoj između 1945. i 1985. godine (A magyarországi italianisztika bibliográfiája / Bibliografia del'italianistica in Ungheria. 1945-1985, 1999. g.). Bio je suurednik izdanja Szlavisztika a magyar felsőoktatásban [Slavistika u visokom školstvu u Mađarskoj] (1999, urednici István Nyomárkay, Ildikó Kálmán), Hadrovics László: A régi horvát szótárirodalom. Magántanári elöadások az 1941/1942. tanévben [Stara hrvatska leksikografija. Predavanja privatnog docenta iz akademske godine 1941/42] (2002, urednik István Nyomárkay), Kis szláv lexikográfia [Mala slavenska leksikografija] (2004, urednik István Nyomárkay), Rukopisne prodike iz Pannonhalme (2005, urednik István Nyomárkay). Aktivno sudjeluje i drži predavanja na međunarodnim i domaćim znanstvenim romanističkim i slavističkim skupovima i konferencijama od Trsta preko Dubrovnika do Budimpešte.

Profesor Vig o svojim omiljenim temama uvijek govori s velikim oduševljenjem. On je precizan čovjek koji je u svom radu precizan i točan, čovjek koji uvijek rado pomaže ne samo kolegama nego i studentima koji s voljom pišu diplomske radove pod njegovim mentorstvom. Uvijek je na raspolaganje svima kad trebaju pomoć. Profesor Vig rado podržava studente na postdiplomskim studijima i pomaže im na početku njihove znanstvene karijere. Sa zadovoljstvom se sjećam njegovih predavanja i seminara koji su bili uvijek zanimljivi i dinamični. Svoje interesovanje prema zanimljivostima jezika i istraživanjima prenio je i na nas, njegove nekadašnje studente.

Dragi profesore, dragi Istváne, želim ti još mnogo aktivnih godina, punih istraživačkih zadataka i tema, dobro zdravlje i još mnogo rasprava, konferencija i monografija za budućnost.

Elöd Dudás 